\title{
KOMUNIKASI TERAPEUTIK PERAWAT PADA TINGKAT KEPUASAN PASIEN: STUDI KASUS DI RUMAH SAKIT ULIN BANJARMASIN
}

\author{
Muhammad Ra'uf \\ Email: raufkhansetia@gmail.com \\ Fakultas Keperawatan dan Ilmu Kesehatan Universitas Muhammadiyah Banjarmasin \\ Jln. S. Parman. Kompleks RS Islam, Banjarmasin, Kalimantan Selatan 70114
}

\begin{abstract}
ABSTRAK
Tujuan penelitian ini adalah untuk mengetahui Hubungan Komunikasi Terapeutik Dengan Tingkat Kepuasan Pasien di Rumah Sakit Ulin Banjarmasin. Kepuasan pasien menjadi tanggungjawab pihak pelayanan kesehatan. Fasilitas dan pelayanan kesehatan yang sesuai dengan harapan pasien, tidak menutup kemungkinan pasien tersebut akan selalu datang dan berobat pada layanan kesehatan tersebut. Ketidakpuasan pasien terhadap pelayanan kesehatan salah satunya dipengaruhi oleh faktor komunikasi terapeutik perawat dalam memberikan asuhan keperawatan.

Desain penelitian adalah penelitian korelasional dengan pendekatan cross sectional. Populasinya semua pasien di Rumah Sakit Ulin Banjarmasin.sejumlah 60 pasien. Tehnik sampling menggunakan simple ramdom sampling dengan sampel sebagian respondenberjumlah 52 responden. Variabel independen komunikasi terapeutik dan variabel dependennya kepuasanpasien. Instrumen penelitian menggunakan kuesioner dengan pengolahan data editing, coding, entry data dan tabulating dan analisa data menggunakan uji rank spearman.
\end{abstract}

Kata Kunci: Komunikasi Terapeutik Perawat, Kepuasan Pasien

\begin{abstract}
The purpose of this study was to determine the relationship between Therapeutic Communication and Patient Satisfaction Levels at Ulin Hospital, Banjarmasin. Patient satisfaction is the responsibility of the health service. Health facilities and services that are in accordance with patient expectations, do not rule out the possibility that these patients will always come and seek treatment at these health services. One of the patient's dissatisfaction with health services is influenced by the therapeutic communication factor of nurses in providing nursing care.

The research design is a correlational study with a cross sectional approach. The population is all patients at Ulin Hospital, Banjarmasin. A total of 60 patients. Sampling technique using simple random sampling with a sample of some respondents totaling 52 respondents. The independent variable is therapeutic communication and the dependent variable is patient satisfaction. The research instrument used a questionnaire with data processing editing, coding, data entry and tabulating and data analysis using the Spearman rank test.
\end{abstract}

Keywords: Nurse Therapeutic Communication, Patient Satisfaction

Muhammad Ra'uf | 37 


\section{PENDAHULUAN}

Komunikasi merupakan salah satu yang dapat mempengaruhi kepuasan pasien. Kepuasan pasien menjadi tanggungjawab pihak pelayanan kesehatan. Fasilitas dan pelayanan kesehatan yang sesuai dengan harapan pasien, tidak menutup kemungkinan pasien tersebut akan selalu datang dan berobat pada layanan kesehatan tersebut. Pasien akan selalu mencari pelayanan kesehatan yang sesuai dengan harapannya. Jika tidak sesuai harapan pasien akan mencari fasilitas layanan kesehatan yang lebih baik atau tidak mengecewakan. (Imbalo, 2006). Berdasarkan hasil penelitian sebelumnya terlihat bahwa ketidakpuasan pasien terhadap pelayanan kesehatan salah satunya dipengaruhi oleh faktor komunikasi terapeutik perawat seperti kurangnya senyuman dalam memberikan asuhan keperawatan. Banyak yang mengira atau berpendapat bahwa komunikasi terapeutik identik dengan senyum dan bicara lemah lembut. Hal ini tidak salah tetapi terlalu menyederhanakan arti dari komunikasi terapeutik itu sendiri, karna inti dari komunikasi terapeutik adalah komunikasi yang dilakukan untuk terapi. (Suryani, 2005)

Hasil penelitian Huda (2010), tentang hubungan komunikasi terapeutik perawat dengan tingkat kepuasan pasien di RS Bunda Margonda Depok, bahwa tingkat kepuasan pasien sangat dipengaruhi oleh komunikasi terapeutik perawat, dan 31 pasien sebagai responden didapatkan 19 pasien $(61,3)$ menyatakan puas dan 12 pasien $(38,7)$ menyatakan kurang puas. Selain itu, menurut hasil penelitian yang dilakukan Husna, dkk (2009) tentang hubungan komunikasi terapeutik perawat dengan kepuasan pasien di RS Siti Khotijah sepanjang telah menerapkan komunikasi terapeutik (100\%) dan pasien menyatakan puas $(84,6 \%)$. Sedangkan penelitian yang dilakukan $\mathrm{Hj}$. Indirawati di RSU Haji Sukolilo Surabaya pada tahun 2007 bahwa kepuasan pasien terhadap komunikasi terapeutik perawat $54,2 \%$ tidak puas, sebanyak $16,7 \%$ cukup puas dan $29,2 \%$ sangat puas.

Kepuasan pasien dipengaruhi oleh beberapa faktor, seperti kesesuaian antara harapan dan kenyataan, tingkat pelayanan dirumah sakit, biaya, promosi atau iklan yang sesuai dengan kenyataan, dan komunikasi terapeutik yang baik. Komunikasi terapeutik adalah komunikasi yang direncanakan secara sadar, bertujuan dan kegiatannya dipusatkan untuk kesembuhan pasien (Purwanto, 1994 dalam Mundakir, 2006). Perawat penting menggunakan komunikasi terapeutik berguna dalam pelaksanaan keperawatan, sehingga dapat mengetahui apa yang sedang dirasakan dan yang dibutuhkan oleh pasien. Dan dengan komunikasi terapeutik yang ditunjukkan dengan sikap yang hangat, tulus, dan penuh perhatian dapat menimbulkan saling percaya, saling menghargai dan saling menghormati sehingga pasien dapat menerima tingkat mutu pelayanan kesehatan dengan penuh pengertian dan kekecewaan pasien tidak timbul atau dapat dihindarkan.

\section{KAJIAN TEORI \\ Konsep Kepuasan Pasien}

\section{Kepuasan Pasien}

Kepuasan pasien adalah keluaran (outcame), layanan kesehatan. Dengan demikian kepuasan pasien merupakan salah satu tujuan dari peningkatan mutu layanan kesehatan. Kepuasan pasien adalah suatu tingkat perasaan pasien yang timbul sebagai akibat dari kinerja layanan kesehatan yang diperolehnya setelah pasien membandingkan dengan apa yang diharapkannya (Pohan, 2013).

Instrument kepuasan pasien berdasarkan lima karakteristik (Nursakam, 2013):

a. Kenyataan (tangible) merupakan wujud langsung yang meliputi fasilitas fisik, yang mencakup kemutahiran peralatan yang digunakan, kondisi sarana, kondisi SDM, dan keselarasan antara fasilitas fisik dengan jenis jasa yang diberikan. 
b. Keandalan (Reliability) yaitu pelayanan yang disajikan dengan segera dan memuaskan dan merupakan aspek-aspek keandalan sistem pelayanan yang diberikan oleh pemberi jasa diantaranya kesesuaian pelaksanaan pelayanan dengan rencana.

c. Tanggungjawab (Responsiveness) yaitu keinginan untuk membantu dan menyediakan jasa yang dibutuhkan konsumen.

d. Jaminan (Assurance) yaitu adanya jaminan bahwa jasa yang ditawarkan memberikan jaminan kepastian terhadap tanggungjawab.

e. Empati (Emphaty) memberikan perhatian yang tulus dan bersifat individual atau pribadi yang diberikan kepada para pasien dengan berupaya memahami keinginan pasien.

\section{Rumus Kepuasan Pasien}

Kepuasan pengguna jasa layanan kesehatan dapat disimpulkan sebagai selisih kinerja institusi pelayanan kesehatan dengan harapan pasien (Muninjaya, 2013). Dari penjelasan ini, kepuasan pelanggan dapat di rumuskan sebagai berikut: Satisfaction $=\mathrm{f}$ (performance+expectation)

Dari rumus ini dihasilkan tiga kemungkinan:

a. Performance $<$ Expectation. Jika kinerja pelayanan kesehatan lebih jelek dari pada apa yang diharapkan para pengguna, kinerja pelayanan kesehatan akan dipandang jelek oleh penggunanya, karena tidak akan seseuai dengan harapan pengguna sebelum menerima pelayanan kesehatan.

b. Performance=Expectation. Jika kinerja pelayanan kesehatan sama dengan harapan para penggunanya, pengguna layanan kesehatan akan menerima kinerja pelayanan kesehatan dengan baik. Pelayanan yang diterima sesuai apa yang diharapkan penggunanya. Hasilnya, para pengguna pelayanan merasa puas dengan layanan yang diterima.

c. Performance $>$ Expectation. Jika kinerja layanan kesehatan lebih tinggi dari apa yang diharapkan pengguna, pengguna akan menerima layanan yang melebihi harapannya. Hasilnya, para pelanggan merasa sangat puas dengan pelayanan kesehatan yang diterima.

3. Cara Mengukur Kepuasan Pasien

Mereka yang membeli atau menggunakan produk atau jasa pelayanan kesehatan disebut pelanggan atau costumer (Muninjaya, 2013). Lebih lanjut menurut kolter dalam Nursalam (2011) ada beberapa cara mengukur kepuasan pelanggan atau pasien, antara lain:

a. Sistem keluhan dan saran. Seperti kotak saran di lokasi-lokasi strategis, kartu pos berprangko, saluran telepon bebas pulsa, website, email dan lain-lain.

b. Survei kepuasan pelanggan. Baik via pos, telepon, email maupun tatap muka langsung. 
c. Ghost shopping. Salah satu bentuk observasi yang memakai jasa orang yang menyamar sebagai pelanggan atau pesaing untuk mengamati aspek-aspek pelayanan dan kualitas produk.

d. Lost costumer analisys. Yaitu menghubungi atau mewawancarai pelanggan yang telah beralih dalam rangka memahami penyebab dengan melakukan perbaikan pelayanan.

\section{Konsep Komunikasi Terapeutik}

Menurut Stuart (2006), tahapan komunikasi terapeutik ada empat tahap, dimana setiap tahap mempunyai tugas tersendiri yang harus diselesaikan oleh tenaga kesehatan.

a. Fase Prainteraksi

Prainteraksi dimulai sebelum kontrak pertama dengan pasien. Tenaga kesehatan mengumpulkan data tentang pasien, menyusun intervensi, mengekplorasi perasaan, fantasi dan ketakutan.

b. Fase Orientasi

Fase ini dimulai ketika tenaga kesehatan pertama kali bertemu dan kontak langsung dengan pasien. Pada tahap ini tenaga kesehatan memberi salam, senyum, melakukan validasi (kognitif, psikomotor, afektif), memperkenalkan nama, menanyakan nama pasien, menjelaskan kegiatan yang akan dilakukan, kontrak waktu yang dibutuhkan untuk melakukan kegiatan, menjelaskan kerahasiaan dari pasien. Tujuan akhir pada fase ini ialah terbina hubungan saling percaya antara petugas kesehatan dengan pasien.

c. Fase Kerja

Pada tahap kerja dalam komunikasi terapeutik, kegiatan yang dilakukan adalah memberikan kesempatan kepada pasien untuk bertanya, menanyakan keluhan utama, memulai kegiatan dengan cara yang baik, melakukan kegiatan sesuai intervesi sebelumnya. Tenaga kesehatan membantu memenuhi kebutuhan dan mengembangkan pola-pola adaptif pasien. Interaksi yang memuaskan akan menciptakan suasana yang meningkatkan integritas pasien dengan meminimalisasi ketakutan, ketidakpercayaan, kecemasan, dan tekanan pada pasien, serta bisa membuat pasien terbuka kepada petugas kesehatan.

d. Fase Terminasi

Pada tahap terminasi dalam komunikasi terapeutik yang dilakukan oleh tenaga kesehatan adalah menyimpulkan hasil wawancara atau diskusi, tindak lanjut dengan pasien melakukan kontrak (waktu, tempat, dan topik), mengakhiri wawancara dengan cara yang baik.

\section{Faktor yang Mempengaruhi Komunikasi Terapeutik}

Menurut Tamsuri (2005), dalam melakukan komunikasi, salah satunya komunikasi terapeutik dapat dipengaruhi beberapa hal sebagai berikut:

a. Perkembangan

Agar dapat berkomunikasi efektif tenaga kesehatan harus mengerti pengaruh perkembangan usia baik dari sisi bahasa, cara berfikir dan proses berfikir dari orang tersebut. Cara berkomunikasi pada usia dewasa dengan usia balita tentunya berbeda, pada usia dewasa kita 
barangkali perlu belajar bahasa "gaul" mereka sehingga yang kita ajak bicara akan merasa kita mengerti mereka dan komunikasi diharapkan akan lancar.

b. Persepsi

Persepsi adalah pandangan pribadi seseorang dalam mengenali suatu kejadian atau peristiwa. Persepsi ini, dibentuk oleh pengalaman dan harapan. Perbedaan suatu persepsi dapat mengakibatkan perdebatan dan terhambatnya komunikasi.

c. Nilai

Nilai adalah sesuatu yang mempengaruhi perilaku sehingga penting bagi perawat untuk menyadari nilai dari seorang pasien. Perawat perlu berusaha untuk mengetahui dan mengklarifikasi nilai sehingga dapat membuat keputusan dan interaksi yang tepat dengan pasien. Dalam hubungan profesionalnya diharapkan tenaga ksesehatan tidak terpengaruh oleh nilai pribadinya.

d. Latar Belakang Sosial Budaya

Bahasa dan gaya komunikasi sangat dipengaruhi oleh faktor budaya. Budaya juga akan membatasi cara bertindak dan berkomunikasi seseorang.

e. Emosi

Emosi merupakan perasaan subjektif terhadap suatu kejadian, seperti marah, sedih, senang akan dapat mempengaruhi tenaga kesehatan dalam berkomunikasi dengan orang lain. Perawat perlu mengkaji emosi pasien dan keluarga sehingga perawat mampu memberikan asuhan keperawatan dengan tepat dan baik. Selain itu perawat juga perlu mengevaluasi emosi pada dirinya sendiri agar dalam memberikan asuhan keperawatan tidak terpengaruh oleh emosi dibawah sadarnya.

f. Jenis Kelamin

Setiap jenis kelamin mempunyai gaya berkomunikasi yang berbedabeda. Tanned (1990) menyebutkan bahwa pria dan wanita mempunyai perbedaan gaya komunikasi. Dari usia 3 tahun wanita ketika bermain dalam kelompoknya menggunakan bahasa untuk mencari kejelasan, meminimalkan sebuah perbedaan, serta membangun dan mendukung keintiman, sedangkan laki-laki menggunakan bahasa untuk

kemandirian aktifitas bermainnya, dimana jika mereka ingin berteman maka mereka melakukannya dengan cara bermain.

g. Pengetahuan

Tingkat pengetahuan sangat mempengaruhi komunikasi yang dilakukan. Seseorang yang tingkat pengetahuannya rendah akan sulit merespon pertanyaan yang mengandung bahasa verbal dibanding dengan seseorang yang memiliki tingkat pengetahuan tinggi. Perawat perlu mengetahui tingkat pengetahuan pasien sehingga perawat dapat berinteraksi dengan baik dan akhirnya dapat memberikan suatu asuhan keperawatan yang tepat pada pasien.

h. Peran dan Hubungan

Gaya komunikasi sesuai dengan peran dan hubungan antar orang yang terlibat komunikasi. Cara komunikasi seorang perawat dengan sejawatnya, dengan cara komunikasi seorang 
perawat pada pasien akan berbeda tergantung perannya. Demikian juga antara guru dengan muridnya.

\section{i. Lingkungan}

Lingkungan dapat mempengaruhi komunikasi yang efektif. Suasana bising, ramai, tidak ada privasi yang tepat akan menimbulkan kerancuan, ketegangan dan ketidaknyamanan dari pasien.

j. Jarak

Jarak akan mempengaruhi komunikasi. Jarak tertentu menyediakan rasa aman dan kontrol tersendiri. Dapat dimisalkan dengan pasien yang merasa terancam ketika seseorang tidak dikenal tiba-tiba berada pada jarak yang sangat dekat dengan dirinya. Hal ini juga yang dialami oleh pasien pada saat pertama kali berinteraksi dengan perawat. Untuk itu perawat perlu memperhitungkan jarak pada saat melakukan hubungan dengan pasien.

k. Masa Kerja

Masa kerja adalah waktu dimana seseorang mulai bekerja disebuah tempat. Semakin lama seseorang bekerja semakin banyak pengalaman yang dimilikinya sehingga semakin baik pula komunikasinya.

\section{METODE PENELITIAN \\ Rancangan Penelitian}

Penelitian ini termasuk dalam penelitian kuantitatif dengan rancangan penelitian koralesional menggunakan Cross sectional. Pendekatan cross sectional yaitu merupakan penelitian sectional silang dengan variabel sebab atau resiko dan akibat atau kasus yang terjadi pada objek penelitian yang diukur dan dikumpulkan secara simultan sesaat atau satu kali saja dalam satu kali waktu (dalam waktu yang bersamaan) (Setiadi, 2007). 


\section{Jalannya Penelitian (Kerangka Kerja)}

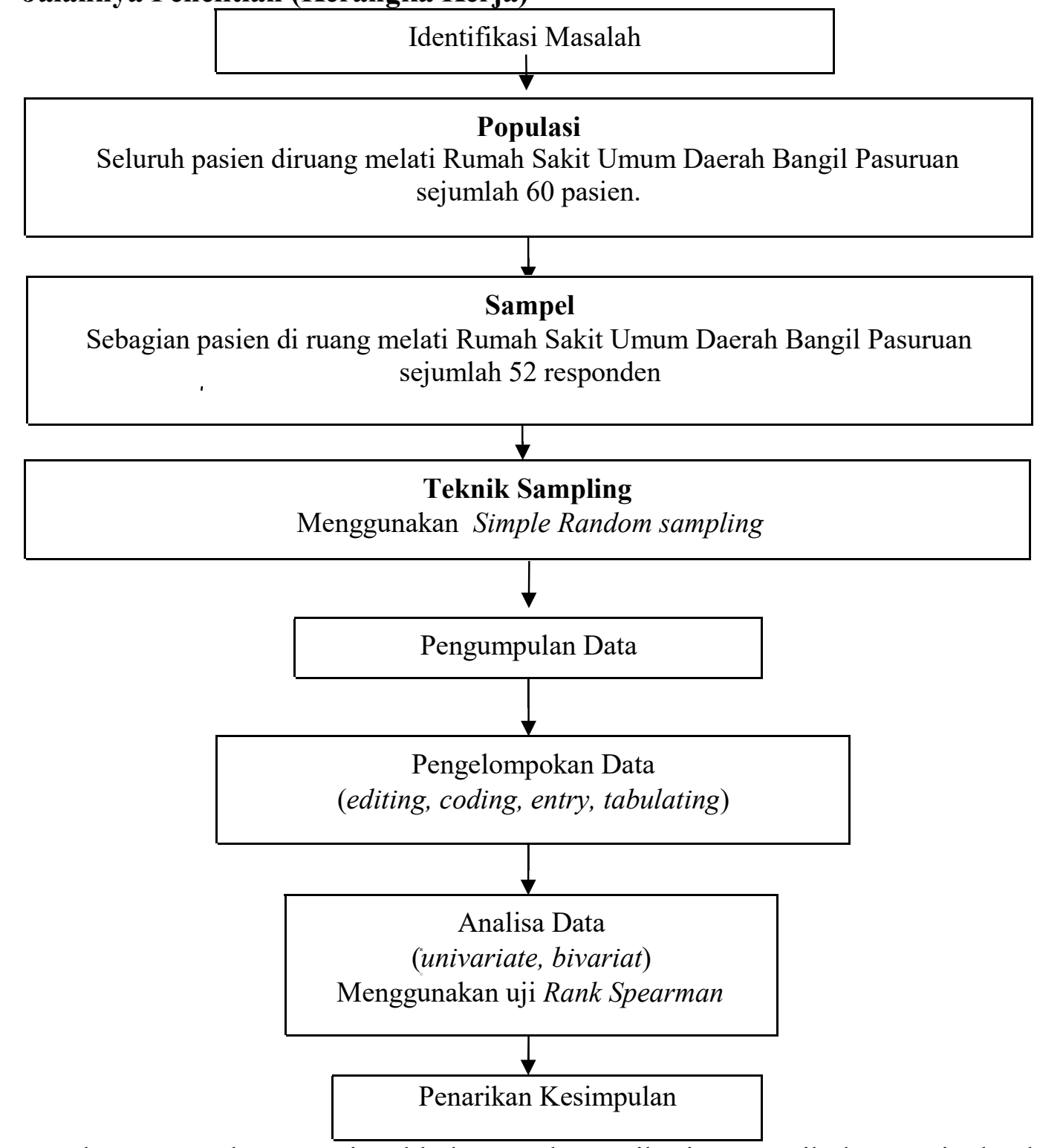

Gambar: Kerangka operasional hubungan komunikasi terapeutik dengan tingkat kepuasan pasien di ruang melati Rumah Sakit Umum Daerah Bangil Pasuruan

\section{HASIL PENELITIAN DAN PEMBAHASAN}

\section{Pembahasan}

1. Komunikasi Terapeutik

Hasil penelitian ini menunjukkan pelaksanaan komunikasi terapeutik perawat ruang rawat inap di Rumah Sakit Ulin Banjarmasin sebagian besar adalah kurang baik sebanyak 24 orang (46,1\%). Menurut peneliti kurangnya komunikasi terapeutik perawat dikarenakan banyaknya pasien perhari mencapai 60 (29.8) tidak sebanding dengan jumlah perawat yang dinas per shift sejumlah 14 (35.9), sehingga kinerja perawat tidak maksimal.

Menurut teori Wahyu (2006), menyatakan bahwa pada fase kerja merupakan inti dari keseluruhan proses komunikasi terapeutik, karena di dalamnya perawat dituntut untuk membantu dan mendukung pasien untuk menyampaikan perasaan dan pikirannya dan 
kemudian menganalisis respons ataupun pesan yang disampaikan oleh pasien. Dalam tahap kerja adalah tahap dimana perawat - pasien memiliki waktu bertatap muka lebih lama dan perawat pula mendengarkan secara aktif dan dengan penuh perhatian sehingga mampu membantu pasien untuk mendefiniikan masalah kesehatannya

Berdasarkan data dari kuesioner pada parameter "bersikap sopan" dengan pernyataan "perawat mencondongkan tubuh kearah anda" didapatkan hasil menjawab tidak adalah 38 (73\%) responden.

Menurut teori Kendon (2014), gesture tubuh seperti mencondongkan diri merupakan suatu bentuk komunikasi non verbal dengan aksi tubuh yang terlihat mengkomunikasikan pesan-pesan tertentu, baik sebagai pengganti wicara atau bersamaan dan pararel dengan katakata.

Berdasarkan data dari kuesioner komunikasi terapeutik terdapat nilai terendah pada parameter "rileks" dengan pernyataan "perawat bersikap rileks kepada saya" didapatkan hasil menjawab tidak adalah 39 (75\%) responden.

Menurut Egan (2013), salah satu sikap atau cara umtuk menghadirkan diri secara fisik yang dapat memfasilitasi komunikasi yang terapeutik yaitu tetap rileks, tetap dapat mengontrol keseimbangan antara ketegangan dan relaksasi dalam memberi respon respon kepada klien.

2. Kepuasan Pasien

Hasil penelitian menunjukkan sebagian besar pasien merasa kurang puas terhadap pelayanan yang diberikan di ruang rawat inap di Rumah Sakit Ulin Banjarmasin sebanyak 27 orang $(51,9 \% \%)$. Menurut peneliti ketidakpuasan responden dikarenakan pelayanan keperawatan yang diberikan belum memuaskan.

Menurut teori Budiastuti (2002) yang mempengaruhi kepuasan pasien adalah pelayanan keperawatan terutama komunikasi yaitu tata cara informasi yang diberikan oleh pihak penyedia jasa dan bagaimana keluhan- keluhan dari pasien dengan cepat diterima oleh penyedia jasa terutama perawat dalam memberikan bantuan terhadap keluhan pasien. Misalnya adanya tombol panggilan di dalam ruang rawat inap, adanya ruang informasi yang memadai terhadap informasi yang akan dibutuhkan pemakai jasa rumah sakit, seperti keluarga pasien maupun orang yang berkunjung ke rumah sakit.

Berdasarkan data, kepuasan pasien terhadap mutu pelayanan keperawatan di ruang rawat inap di Rumah Sakit Ulin Banjarmasin sebagian besar berjenis kelamin laki-laki sebanyak 34 orang $(65,3 \%)$. Menurut peneliti jenis kelamin dapat mempengaruhi kepuasan pasien, hal ini dikarenakan ada perbedaan tingkat kepuasan antara laki-laki dan perempuan.

Menurut teori Haydar (2011) menyatakan bahwa faktor demografi yang berhubungan dengan kepuasan salah satunya adalah jenis kelamin. perempuan lebih mudah puas 63\% dibandingkan laki-laki.

Berdasarkan data umum umur responden, hampir setengah 26-35 tahun (dewasa awal) sebanyak 24 orang $(46,1 \%)$. Menurut peneliti, faktor lain yang mempengaruhi tingkat kepuasan adalah usia pasien karna semakin tua umur seseorang maka semakin mudah merasa puas.

Menurut teori Anoraga (2009) ada kecenderungan konsumen yang lebih tua lebih merasa puas dari konsumen yang berumur relatif lebih muda. Hal ini diasumsikan bahwa konsumen yang lebihtua telah berpengalaman sehingga ia mampu menyesuaikan diri dengan kondisi pelayanan yang sebenarnya, sedangkan konsumen usia muda biasanya mempunyai harapan yang ideal tentang pelayanan yang diberikan, sehingga apabila harapannya dengan realita pelayanan terdapat kesenjangan, atau ketidakseimbangan dapat meyebabkan mereka menjadi tidak puas. 
Menurut data umum pekerjaan hampir setengahnya responden bekerja sebagai buruh 17 orang (32,7\%). Menurut peneliti, faktor lain yang menyebabkan kepuasan seseorang adalah pekerjaan responden karena juga mempengaruhi tingkat kepuasan pasien.

Menurut teori Lestari (2009), pekerjaan mempengaruhi tingkat kepuasan pasien terhadap pelayanan keperawatan yang diterimanya.

3. Hubungan Komunikasi Terapeutik Dengan Tingkat Kepuasan Pasien di Rumah Sakit Ulin Banjarmasin.

Berdasarkan penelitian dari 52 responden yang diteliti, hasil analisa menunjukkan hahwa responden mengatakan komunikasi terapeutik perawat kurang dengan responden mengatakan kepuasan rendah sebanyak 21 responden (40,3\%)

Hasil uji statistik dimana nilai $\mathrm{p}=0,00$ dengan tingkat kemaknaan $\mathrm{a}=0,05$ yang berarti nilai $\mathrm{p}<\mathrm{a}$ dengan demikian $\mathrm{H} 0$ ditolak dan $\mathrm{H} 1$ diterima atau ada hubungan komunikasi terapeutik dengan tingkat kepuasan pasien di Rumah Sakit Ulin Banjarmasin.

Menurut peneliti, komunikasi yang kurang sangat mempengaruhi tingkat kepuasan pasien. Komunikasi yang dilakukan perawat meliputi komunikasi verbal dan non verbal, perawat yang berkomunikasi dengan sikap tidak bersahabat dan cara berkomunikasi yang tidak baik menyebabkan ketidakpuasan pada pasien, hal ini disebabkan karena ketidakmampuan pasien menafsirkan pesan verbal dan non verbal yang disampaikan perawat.

Menurut teori Suryani (2005), yang menyatakan ketidakpuasan pasien yang paling sering ditemukan erat kaitanya dengan sikap dan prilaku petugas RS, antara lain: lamanya waktu tunggu, lingkungan RS, sikap, prilaku, keramahan petugas, serta kemudahan mendapatkan informasi dan komunikasi menjadi kunci ketidakpuasan pasien di RS sehingga pasien mencari pelayanan kesehatan lainya

\section{KESIMPULAN}

Berdasarkan hasil penelitian yang telah dilakukan oleh peneliti, maka dapat diambil kesimpulan sebagai berikut:

Hasil komuniaksi terapiutik dalam penelitian ini menunjukkan pelaksanaan komunikasi terapeutik perawat ruang rawat inap di Rumah Sakit Ulin Banjarmasin sebagian besar adalah kurang baik sebanyak 24 orang (46,1\%). Menurut peneliti kurangnya komunikasi terapeutik perawat dikarenakan banyaknya pasien perhari mencapai 60 (29.8) tidak sebanding dengan jumlah perawat yang dinas per shift sejumlah 14 (35.9), sehingga kinerja perawat tidak maksimal.

Hasil Kepuasan Pasien dalam penelitian ini menunjukkan sebagian besar pasien merasa kurang puas terhadap pelayanan yang diberikan di ruang rawat inap di Rumah Sakit Ulin Banjarmasin sebanyak 27 orang $(51,9 \% \%)$. Menurut peneliti ketidakpuasan responden dikarenakan pelayanan keperawatan yang diberikan belum memuaskan.

Hubungan Komunikasi Terapeutik Dengan Tingkat Kepuasan Pasien di Rumah Sakit Ulin Banjarmasin. Berdasarkan penelitian dari 52 responden yang diteliti, hasil analisa menunjukkan hahwa responden mengatakan komunikasi terapeutik perawat kurang dengan responden mengatakan kepuasan rendah sebanyak 21 responden (40,3\%) Hasil uji statistik dimana nilai $\mathrm{p}=$ 0,00 dengan tingkat kemaknaan $\mathrm{a}=0,05$ yang berarti nilai $\mathrm{p}<\mathrm{a}$ dengan demikian $\mathrm{H} 0$ ditolak dan $\mathrm{H} 1$ diterima atau ada hubungan komunikasi terapeutik dengan tingkat kepuasan pasien di Rumah Sakit Ulin Banjarmasin. 
Jurnal Terapung : Ilmu - Ilmu Sosial , Vol. 3, No. 2, September 2021 ISSN: 2656-2928

\section{DAFTAR PUSTAKA}

Arwani. 2003. Komunikasi Dalam Keperawatan. Jakarta: EGC.

Davison, Gerald C. 2003. Psikologi Abnormal. Jakarta: PT. Rajagrafindo Persada.

Gerson, Richard. F. 2004. Mengukur Kepuasan Pelanggan. Jakarta: PPM.

Hajarudin. 2014. Hubungan Antara Komunikasi Terapeutik Perawat Dengan Tingkat Kepuasan Pasien Di Puskesmas Pleret Bantul Yogyakarta. Skripsi tidak diterbitkan. Yogyakarta: Universitas Muhammadiyah Yogyakarta.

Haryanti, 2000. Manajemen Mutu Pelayanan Kesehatan. Surabaya: Universitas Airlangga.

Imbalo, S. 2006. Jaminan Mutu Layanan Kesehatan: Dasar-Dasar Pengertian dan Penerapan. Jakarta: EGC

Lovelock, Christopher, \& Jochen Wirtz. 2007. Manajemen Pemasaran Jasa. Jakarta: Indeks.

Machfoedz, M. 2009. Komunikasi Kepelayan kesehatanan: Komunikasi Terapeutik. Yogyakarta: Salemba

Muhit, A., Mubarak, \& Nasir. 2009. Komunikasi dalam Kepelayan kesehatanan: Teori dan Aplikasi. Jakarta: Selemba Medika.

Mundakir. 2006. Komunikasi Keperawatan: Aplikasi Komunikasi dalamPelayanan. Yogyakarta: Graha Ilmu.

Ngalimun. 2019. Komunikasi Terapeutik Bidan Dan Pasien Pasca Melahirkan Operasi Pada Rumah Sakit Muhammadiyah Palangka Raya. Jurnal Terapung: Ilmu-Ilmu Sosial dengan e-ISSN:2656-2928. Vol. 1 No. 2 Tahun 2019.

Pondaag, dkk. 2014. Hubungan Komunikasi Terapeutik Pelayan kesehatan dengan Kepuasan pasien di Ruang Rawat Inap Irina A RSUP Prof. Dr. R D. Kandou Manado. Skripsi tidak diterbitkan. Manado: Universitas Sam Ratulangi.

Sareong, Kiky Miranti dkk. 2013. Faktor yang Berhubungan dengan Kepuasan Pasien Rawat Jalan di Puskesmas Rantepao Kabupaten Toraja Utara Tahun 2013. Skripsi tidak diterbitkan. Makassar: Universitas Hasanuddin.

Stuart, G. W. \& Sundeen, S. J. 2006. Buku Saku Kepelayan Kesehatanan Jiwa. Alih Bahasa, Achrir. Y. S. Jakarta: EGC

Suryani. 2005. Komunikasi Terapeutik: Teori dan Praktik. Jakarta: EGC

Swarjana, I Ketut. 2015. Metodologi Penelitian Kesehatan (Edisi Revisi). Yogyakarta: ANDI

Tamsuri. 2005. Buku Saku: Komunikasi dalam Kepelayan Kesehatanan. Jakarta: EGC 